\title{
Relative growth and population dynamics of Macrobrachium iheringi (Decapoda, Palaemonidae)
}

\author{
Caio dos Santos Nogueira ${ }^{1,4}$; Júlia Fernandes Perroca ${ }^{1,5}$; Emerson Luiz Piantkoski ${ }^{1,6}$; \\ Rogerio Caetano da Costa ${ }^{1,7}$; Fabiano Gazzi Taddei ${ }^{2}$ \& Adilson Fransozo ${ }^{3}$
}

\footnotetext{
${ }^{1}$ Universidade Estadual Paulista (UNESP), Faculdade de Ciências, Departamento de Ciências Biológicas, Laboratório de Biologia de Camarões Marinhos e de Água Doce (LABCAM). Bauru, SP, Brasil.

2 Universidade do Estado do Amazonas (UEA), Centro de Estudos Superiores de Parintins (CESP), Laboratório de Estudos de Crustáceos da Amazônia (LECAM). Parintins, AM, Brasil. ORCID: http://orcid.org/0000-0001-8297-1705. E-mail: fgtaddei@hotmail.com

${ }^{3}$ Universidade Estadual Paulista (UNESP), Instituto de Biociências, Departamento de Zoologia, Núcleo de Estudos em Biologia, Ecologia e Cultivo de Crustáceos (NEBECC). Botucatu, SP, Brasil. ORCID: http://orcid.org/0000-0002-2067-5406. E-mail: fransozo@ibb.unesp.br

${ }^{4}$ ORCID: http://orcid.org/0000-0001-8539-0551. E-mail: caiosnogueira@hotmail.com

${ }^{5}$ ORCID: http://orcid.org/0000-0002-7274-3941. E-mail: juliaperroca@hotmail.com

${ }^{6}$ ORCID: http://orcid.org/0000-0002-7975-2883. E-mail: emerson.luiz.piantkoski@gmail.com

7 ORCID: http://orcid.org/0000-0002-1342-7340. E-mail: rccosta@fc.unesp.br
}

\begin{abstract}
During the ontogenetic development of crustaceans, the relative growth of some structures may change, especially during the transition from juvenile to adult. This study describes the relative growth of body structures of Macrobrachium iheringi, and provides information on its population dynamics, such as structure, fecundity, and morphological sexual maturity. The sampling of M. iheringi was carried out in "Ribeirão da Hortelã", in Botucatu (SP, Brazil). The length of the carapace (CL), abdomen (AL), and ischium (IL), merus (ML), carpus (CrL), propodus (PpL), and dactyl ( $\mathrm{DCL})$ of the second right pereopod were measured. In addition, the width of the second abdominal pleura (PW) and propodus height (PpH) were included in analyses. The relationships that best demonstrated the changes in the allometric coefficient were $\mathrm{CL}$ vs $\mathrm{PpL}$ in males and females. The $\mathrm{CL}$, in which males and females reach morphological sexual maturity, was estimated as $13.3 \mathrm{~mm}$ and $11.1 \mathrm{~mm}$, respectively. The sex-ratio differed from the expected 1:1 and was skewed towards females. Precipitation and temperature influenced the abundance of different demographic classes. Macrobrachium iheringi has few but large eggs, which is expected since this species has an abbreviated larval development. Based on these results, we conclude that the propodus are good indicators of the size at onset of morphological sexual maturity. In addition, important information was obtained on the biology of M. iheringi, including its life cycle pattern, reproduction and influence of abiotic factors.
\end{abstract}

Key-Words. Allometry; Freshwater; Caridea; Populations; Sex-ratio.

\section{INTRODUCTION}

In Brazil, currently, 35 species of freshwater prawns are known, belonging to three families: Atyidae, Euryrhynchidae and Palaemonidae (Magalhães et al., 2016). Among the Palaemonidae, 19 species of Macrobrachium Spence Bate, 1868 are known, which, besides being the most abundant genus (Mantelatto et al., 2016), is of great commercial interest. Even though, the biological aspects of only a few species are known, especially the ones of economic importance (Mantelatto et al., 2016). Among these species, M. iheringi (Ortmann, 1897) is an endemic Brazilian prawn found in cold continental waters (Fransozo et al., 2004) in the states of Goiás, Espirito Santo, São
Paulo, Minas Gerais, Rio de Janeiro, Mato Grosso and Paraná (Pileggi et al., 2013). Previous studies addressed the geographical distribution (Coelho \& Ramos-Porto, 1984; Gomes-Correa, 1977), behavior (Volpato \& Hoshino, 1984), ecophysiology (Favaretto, 1973), reproductive period (Fransozo et al., 2004), growth and longevity (Lobão et al., 1986), and larval development (Bueno \& Rodrigues, 1995) of M. iheringi.

During development, after the embryonic stage, ontogenetic changes in habits, and sexual differentiation and maturation can lead to differences in the relative growth of different structures. Knowledge on these relationships can provide important information on the different life cycle stages, for example, the size at the onset of 
morphological sexual maturity and/or the presence of sexual dimorphism (Hartnoll, 1978, 1982). The growth of these body structures may also vary according to sex and life stage. For example, juveniles invest more in somatic growth to achieve sexual maturity than they invest in the growth of specific structures related to the mating behavior, as adults (Paschoal et al., 2013; Moraes-Riodades \&Valenti, 2002).

The population structure of species of Macrobrachium has a similar pattern: the majority of individuals belonging to the smaller size classes, with fewer individuals in the larger ones (Barros-Alves et al., 2012; Pereira \& Chacur, 2009; Pescinelli et al., 2016; Taddei et al., 2017). Part of this is due to the relative growth of structures related to agonistic behaviors, such as the second pair of chelipeds. In this way, the aggressiveness displayed by some species can, to a certain extent, shape the population structure of a community (Peebles, 1977, 1979; Valenti, 1985; Valenti et al., 1993). Knowledge of the reproductive biology of palaemonid prawns is an important tool to establish biodiversity conservation strategies (Mossolin \& Bueno, 2002). Reproductive characteristics may vary according to individual intrinsic aspects, such as female size and age, as well as according to environmental conditions, and may influence fertility and recruitment (Sastry, 1983; Pereira et al., 2017).

The present study describes the relative growth and population dynamics of $M$. iheringi by identifying the structures that best represent the transition between the juvenile and adult phases and determining the size at the onset of morphological sexual maturity. In addition, we report the size frequency distribution, size of the smallest ovigerous female, sex-ratio, reproductive period, recruitment, and fecundity.

\section{MATERIAL AND METHODS}

\section{Study area and sampling of specimens and environmental factors}

Specimens of $M$. iheringi were collected for two years, from July 1991 to June 1992, and July 1993 to June 1994. The samplings were carried out in "Ribeirão da Hortelã", a first-order stream of the Paranapanema River upper basin, located $880 \mathrm{~m}$ above sea level, in the municipality of Botucatu, central region of the state of São Paulo $\left(22^{\circ} 57^{\prime} \mathrm{S}, 48^{\circ} 26^{\prime} \mathrm{W}\right)$ (Fig. 1). The riverbed consists of sand and mud with about $80 \%$ shade cover by the surrounding riparian forest (except in some sections cleared for cattle grazing. In the early morning, for 90 minutes, two collectors used $2 \mathrm{~mm}$ mesh sieves in the aquatic vegetation near the river bank to obtain both juvenile and adult prawns. The sampling covered a 200-meter long section of the stream.

The prawns were stored in plastic bags and kept frozen until they were taken to the laboratory, where they were preserved in $70 \%$ ethanol until analysis. Specimens were identified at species level according to Melo (2003), separated by sex by the presence of the male appendix on the endopod of the second pleopod (Mantelatto \& Barbosa, 2005) and measured with a digital caliper $(0.01 \mathrm{~mm})$. The body structures of males and females measured and used in the morphometric analysis were

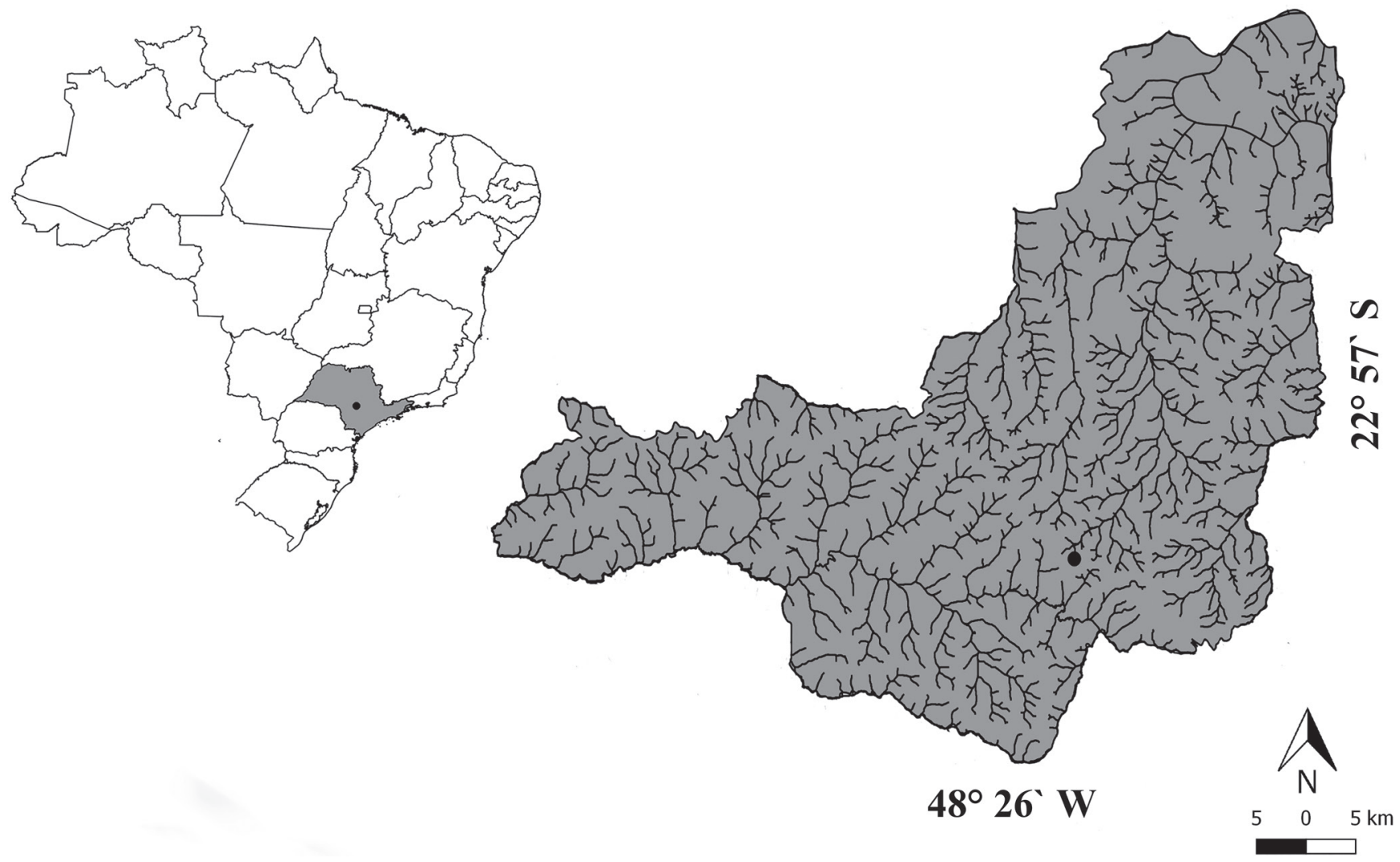

Figure 1. Map showing the sampling site, Ribeirão da Hortelã $\left(22^{\circ} 57^{\prime} \mathrm{S}\right.$ and $\left.48^{\circ} 26^{\prime} \mathrm{W}\right)$, in Botucatu, São Paulo. 

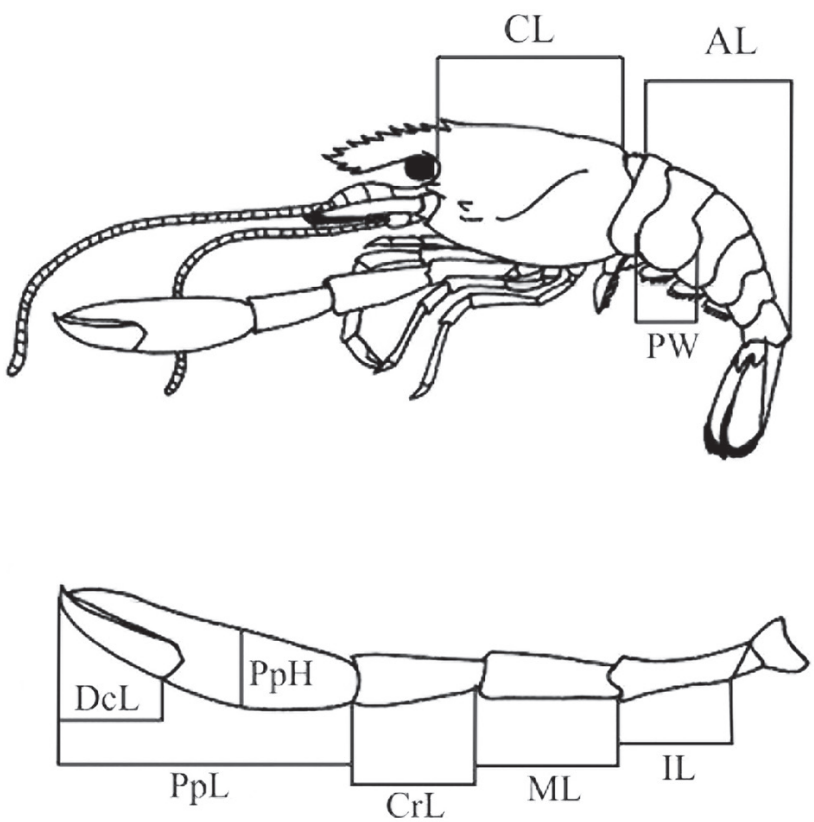

Figure 2. Measurements taken from each specimen of Macrobrachium iheringi (Ortmann, 1897) $(C L$ = carapace length, $P W=$ pleura width, $A L=$ abdomen length. $\mathrm{IL}=$ ischium length, $\mathrm{ML}=$ merus length, $\mathrm{CrL}=$ carpus length, $\mathrm{PpL}=$ propodus length, $\mathrm{DCL}=$ dactyl length and $\mathrm{PpH}=$ propodus height).

the carapace length $(C L)$, pleura width $(P W)$, abdomen length $(A L)$, and ischium length (IL), merus length $(M L)$, carpus length $(\mathrm{CrL})$, propodus length $(\mathrm{PpL})$, dactyl length $(\mathrm{DCL})$, and propodus height $(\mathrm{PpH})$ of the second right pereopod (Fig. 2). Individuals smaller than the smallest recognizable male were considered as sexually undifferentiated and used only in the population structure analyses. The temperature of the water was obtained with a mercury thermometer $\left(0.1^{\circ} \mathrm{C}\right)$, and the rainfall was obtained from the Integrated System of Management of Water Resources of the State of São Paulo.

\section{Analysis of morphotypes (males)}

To check for the presence of different morphotypes in the population, we initially searched for macroscopic morphological differences between the individuals, such as the ornamentation of the chelipeds and the angulation of the spines, as observed in M. amazonicum (Heller, 1862) and M. rosenbergii (De Man, 1879) (Kuris et al., 1987; Moraes-Riodades \& Valenti, 2004; Pantaleão et al., 2014). Then, an exploratory analysis (principal component analysis - PCA) was used with the morphometric data, to verify whether the population could be separated into distinct morphological groups based on the structures analyzed.

\section{Relative growth and determination of morphological sexual maturity}

The Mann-Whitney test was used to investigate the existence of heterochely in the population, a factor that could directly influence the analysis of relative growth.
Then, changes in the growth of different body structures in relation to the independent variable $(C L)$ were verified using the relative growth analysis. The data were plotted and fit to the allometric equation $y=a x^{b}$, where $y$ is the size of a given body structure, $x$ is the length of the carapace, and $b$ is the allometric coefficient (angular) that reflects the angulation of the curve. (Hartnoll, 1974, 1978, 1982). The values of the allometric constant correspond to isometric growth $(b=1)$, positive allometry $(b>1)$ or negative allometry $(b<1)$. To calculate $b$ for each biometric relationship, the data were converted to the linear form by means of natural logarithm transformation (Zar, 2010). The null hypothesis $\left(\mathrm{H}_{0}: \mathrm{b}=1\right)$ was tested with the Student T-test $(a=95 \%)$. Only individuals who had all the previously mentioned structures were used in the analyses. Sexually undifferentiated individuals (UJ) were not considered. After the measurements, the individuals were classified as juveniles or adults, from the differential growth of body structures in relation to the CL. For this, the non-hierarchical K-means analysis was used with the morphometric relationships of males and females separately. This analysis distributes the data into previously established groups (juveniles and adults in our case), by an interactive process that minimizes the variation within groups and maximizes the variation between them. For data overlap, a discriminant analysis was performed with individuals within the overlap range to refine the data for categorization. Both analyzes were based on Sampedro et al. (1999) and Hirose et al. (2013). The breaking point between the groups identified by the discriminant analysis was considered the beginning of morphological sexual maturity. After refining the data, they were subjected to a covariance analysis to compare the angular and linear coefficients between juveniles and adults. This showed whether the data for each relationship were better adjusted in a single line or if juveniles and adults should be represented by different linear equations.

\section{Population structure}

The prawns were distributed in 12 size classes which were established with the method of Sturges (1926). The sex-ratio in adults of the two periods was compared with the Chi-square test $\left(x^{2}\right)(p<0.05)$. The mean total length (TL) of males and females of different demographic classes was compared with the Mann-Whitney test $(a<0.05)$ (Zar, 2010). All statistical analyses were performed using the statistical software PAST v2.17.

\section{Reproductive aspects}

The reproductive period was based on the monthly observation of ovigerous females in sampling years. For the analysis of fecundity, 15 females with an intact egg mass were considered. Spent females were taken into account in the population structure analysis. They were classified by the macroscopic observation of the pleopod region, were it was noticed a recent spawn and 
reminiscent egg mass. The embryonic development of eggs was classified as Early (homogenous color, no visible eye pigments) or Late (eyes completely developed) (Wehrtmann, 1990; García-Guerrero \& Hendrickx, 2009). Ten eggs of each female were carefully removed from the parental pleopods and measured for length and width using a microscope with magnification of $10 x$. Then, the females were immersed in a solution of hypochlorite $(0.05 \%)$ and all eggs were carefully extracted with fine tweezers and counted. The fecundity of each female was calculated as $\mathrm{F}=$ number of eggs per female. Egg volume (VO) was calculated as: VO $=\pi{ }^{*} I^{*} h{ }^{*}(h)^{2}$; where $\mathrm{I}$ is the length in $\mathrm{mm}$; $\mathrm{h}$ is the width in $\mathrm{mm}$ and $\pi=3.14$ (Wehrtmann, 1990). The relationship between fecundity and $C L$ was tested by Simple Linear Regression (Software $R, a=0.05$ ). To investigate a possible influence of environmental factors (water temperature and rainfall) on fecundity and presence of UJ, a time series analysis was used (Cross-correlation, Statistica 7,0, StatSoft, Inc) with $a=0.05$ (Zar, 2010).

\section{RESULTS}

\section{Environmental factors}

During the first sampling year, the highest temperatures were observed in spring and summer, and during the second year in spring, summer and early autumn. The lowest temperatures were recorded in August and September of 1991 and June 1992 in the first sampling year, and in the second in July 1993 and June 1994 (Fig. 3). The highest precipitation was observed in February and
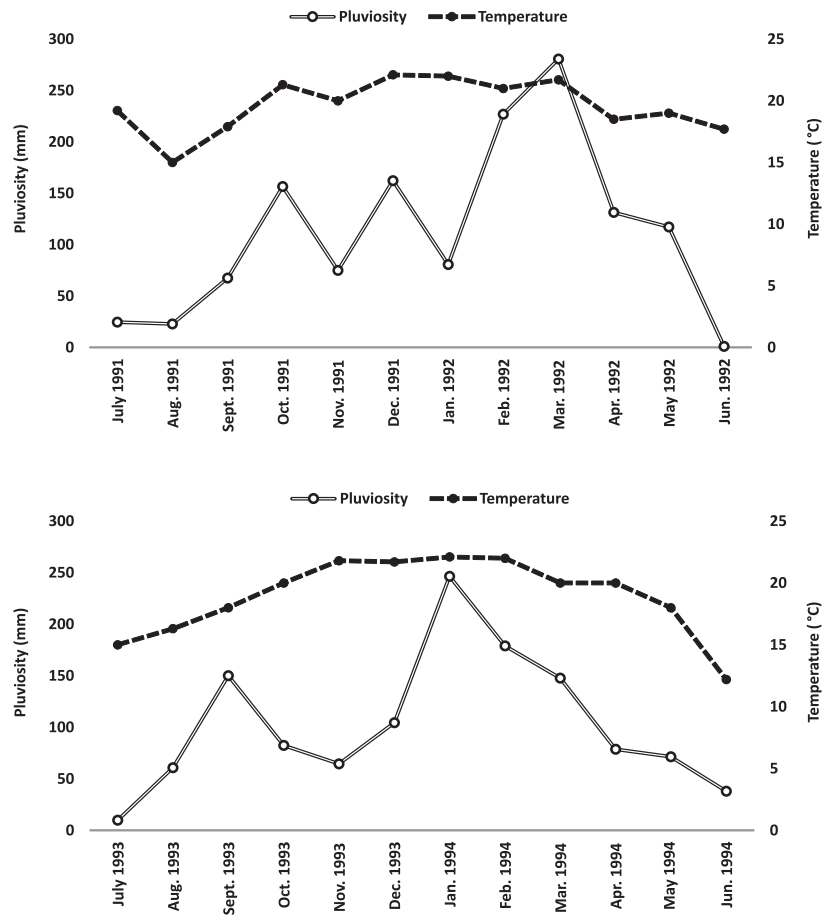

Figure 3. Monthly variation of water temperature and pluviosity during the two sampling periods, July 1991 to June 1992 and July 1993 to June 1994, in Botucatu, state of São Paulo, Brazil.
March of 1992, and in January and February of 1994. July and August of 1991 and June of 1992 had the lowest precipitation in the first year, and July 1993 and June 1994 in the second (Fig. 3).

\section{General data}

Overall, 1478 prawns were captured, but for the screening of potential morphotypes and the analysis of relative growth, only the sexually differentiated individuals with intact articles from the second pair of pereopods were used in the statistical analysis, resulting in 171 males and 197 females. According to the Mann-Whitney test, there was no significant difference $(p>0.05)$ between the size $(\mathrm{mm})$ of left and right chelipeds, therefore, the right cheliped was chosen to analysis performance.

Regarding the analysis of relative growth, the K-means analysis showed a significant difference $(p<0.01)$ in the $\mathrm{PpL}$ vs $\mathrm{CL}$ relationship between juveniles and adults males. The relationship PpL vs CL was positively allometric in adults and isometric in juveniles, thus, in the adults the propodus grows faster than the CL. Based on this relationship, the size at onset of sexual maturity of males was estimated at $13.23 \mathrm{~mm} \mathrm{CL}$ (Fig. 4). As in PpL vs CL, the relation $\mathrm{CrL}$ vs $\mathrm{CL}$ was positively allometric to adult males and negatively to juveniles. All other biometric relationships related to the second pair of chelipods (IL vs CL; $M L$ vs $C L$; $D c L$ vs $C L$ ) showed isometry for adult males and negative allometry for juveniles, with the exception of the $\mathrm{PpH}$ vs $\mathrm{CL}$ relation, which showed positive allometric development for both demographic classes. In relation to the abdomen, $\mathrm{AL}$ vs $\mathrm{CL}$ and $\mathrm{PW}$ vs $\mathrm{CL}$ presented negative allometry in both demographic classes.

The size at onset of morphological sexual maturity in females was estimated to be $11.1 \mathrm{~mm} \mathrm{CL}$ (Fig. 5). In females, a few relationships were significantly different $(p<0.05)$ between juveniles and adults: AL vs $C L$, $\mathrm{PpL}$ vs $\mathrm{CL}$, PpH vs $\mathrm{CL}, \mathrm{DcL}$ vs $\mathrm{CL}$ (Table 2). Regarding the abdomen, the relationship $\mathrm{AL}$ vs $\mathrm{CL}$ and $\mathrm{PW}$ vs $\mathrm{CL}$, was isometric in adults and juveniles. For the second right cheliped, the relationships IL vs $\mathrm{CL}, \mathrm{ML}$ vs $\mathrm{CL}, \mathrm{CrL}$ vs $\mathrm{CL}$ showed the same development pattern between demographic classes, being characterized as negatively allometric. It was observed in the relations $\mathrm{PpL}$ vs $\mathrm{CL}$ and $\mathrm{PpH}$ vs $\mathrm{CL}$ different development patterns between demographic classes, being, positively allometric to adults and negatively allometric and isometric to juveniles, respectively. The relation $\mathrm{DCL}$ vs $\mathrm{CL}$ was characterized by the same development pattern between the demographic classes, being isometric.

No macroscopic evidence of different male morphotypes was found in this population. The same result was obtained by the morphometric analysis: the PCA showed no separation of morphological groups in the adult males. Principal component (PC1) (Table 1, Fig. 6) explained most of variation (93.56\%), and was related to propodus length $(\mathrm{PpL})$. The wide distribution of individuals along the $\mathrm{PC} 1$ suggests a high variation in propodus size from juveniles to adults. 


\section{Populational structure}

A total of 1,478 individuals were collected during the two sampling periods, of which 759 females (with 19 of them carrying eggs), 494 males, and 225 undifferentiated juveniles. The TL range was $16.5-63.5 \mathrm{~mm}$ in non-ovigerous females, 47.4-61.5 $\mathrm{mm}$ in ovigerous females, $19.2-72.0 \mathrm{~mm}$ in males, and $8.6-19.2 \mathrm{~mm}$ in undifferentiated juveniles.
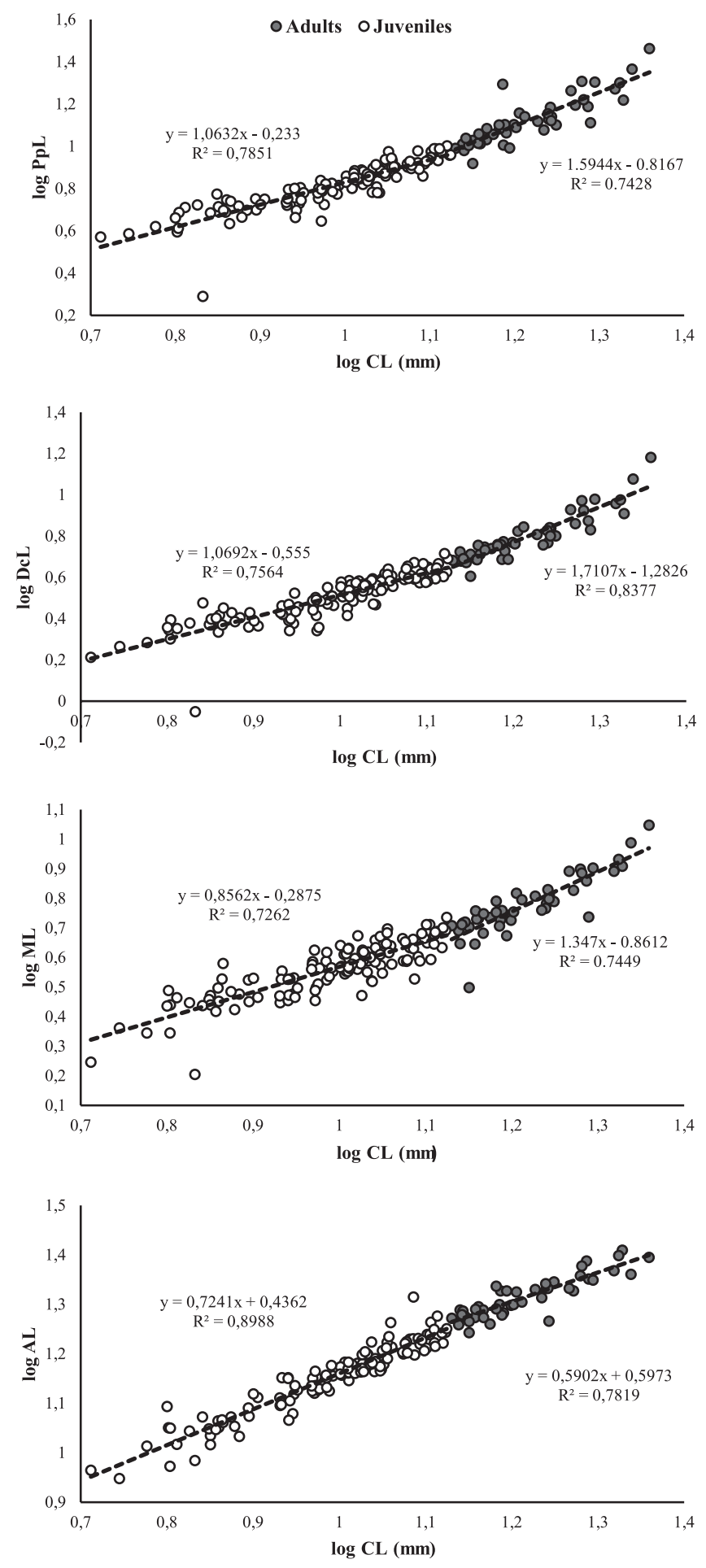

Prawns were distributed in $12 \mathrm{TL}$ size classes of $5.3 \mathrm{~mm}$ intervals. Undifferentiated juveniles were found in the first two size classes, being more abundant in the second (Table 4). The highest absolute frequency of undifferentiated juveniles was found in size class 13.9 [ 19.2 (Table 4). Females were more abundant in the size classes of 19.2 [ 24.5, followed by 24.5 [ 29.8 and 35.1 [ $40.4 \mathrm{~mm}$. Males were more abundant in the classes 24.5 [ 29.8, followed by 29.8 [ 35.1 and
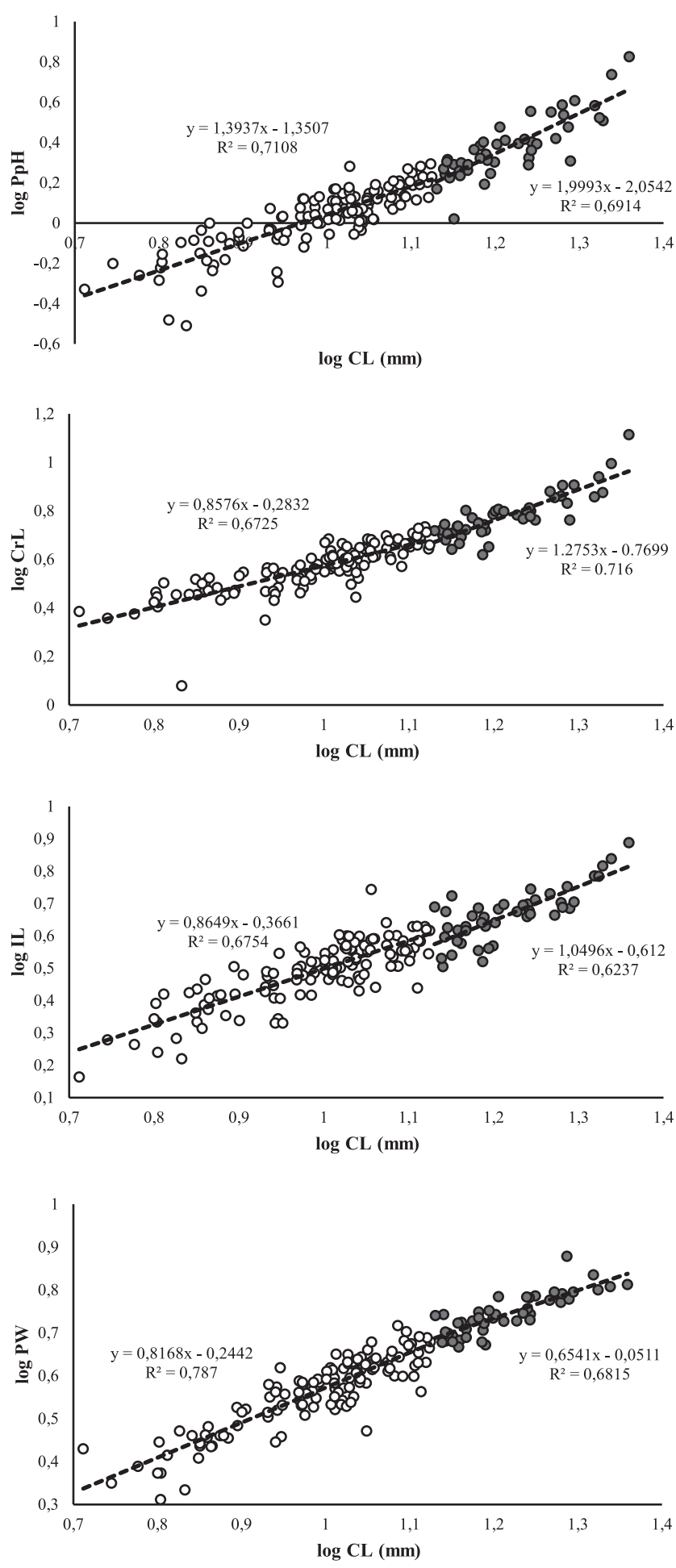

Figure 4. Estimation of the size at onset of morphological sexual maturity of Macrobrachium iheringi (Ortmann, 1897) males. The estimated size is the carapace length (CL) of the smallest adult individual, obtained after the distinction of juvenile (open circles) and adult (black circles) equations. $\mathrm{PW}=\mathrm{pleura}$ width, $\mathrm{AL}=$ abdomen length, $\mathrm{IL}=$ ischium length, $\mathrm{ML}=$ merus length, $\mathrm{CrL}=$ carpus length, $\mathrm{PpL}=$ propodus length, $\mathrm{DcL}=$ dactyl length and $\mathrm{PpH}=$ propodus height. 
35.1 [ $40.4 \mathrm{~mm}$ (Table 4). Comparing the two sampling years, 1991/1992 and 1993/1994, males and females were found all over the year, yet, abundance in rainy months was higher than in the drier ones. In 1991/1992 the abundance of males and females was similar, whereas in 1993/1994 females were more abundant (Figs. 7 and 8).

Regarding the sex ratio, there was a significant bias towards males in the larger size classes, in both years. For
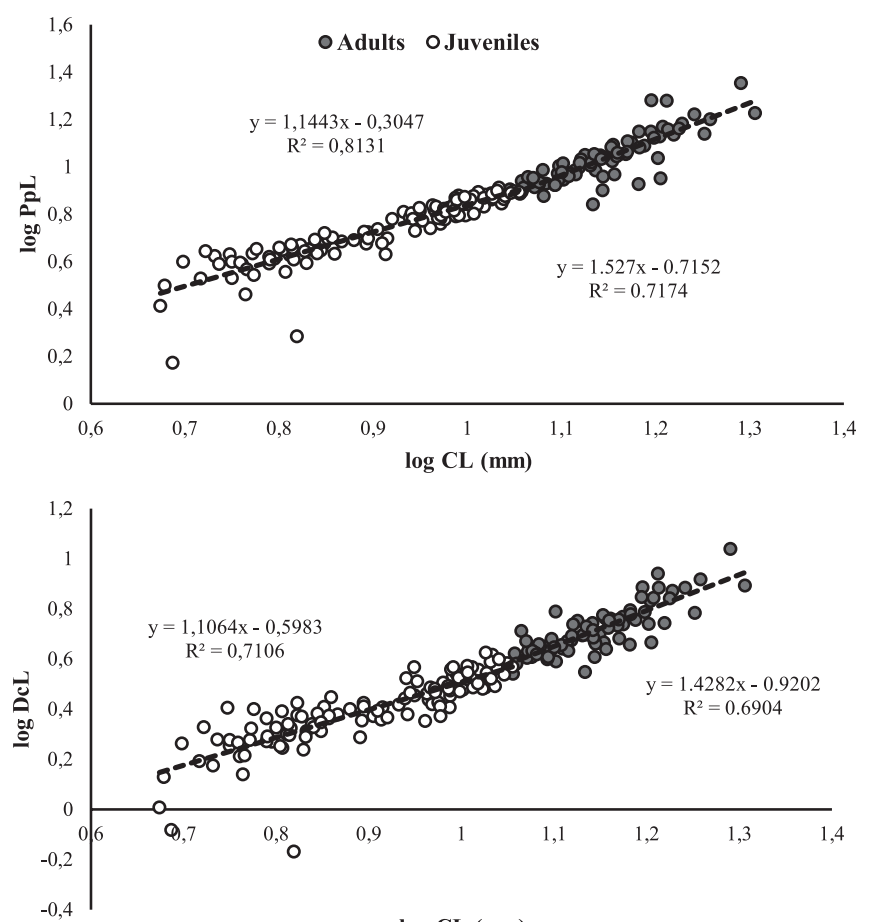

$\log \mathbf{C L}(\mathrm{mm})$
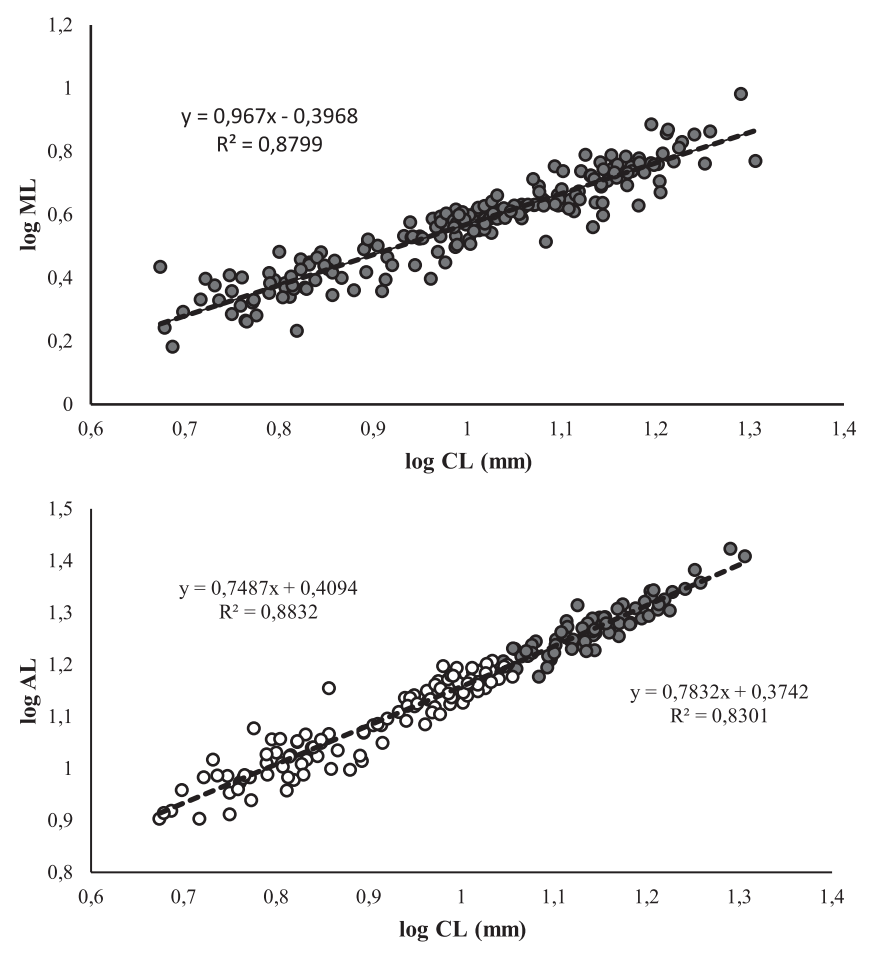

females, there was no significant bias in classes 13.9 [ 9.2, 19.2 [ 24.5, 45.7 [ 50 and 69.9 [ $72.2 \mathrm{~mm}$ (Table 4).

\section{Reproductive aspects}

The reproductive period was seasonal: in the period of July 1991 to June 1992 ovigerous females occurred only in October and February (Fig. 7). In the period of
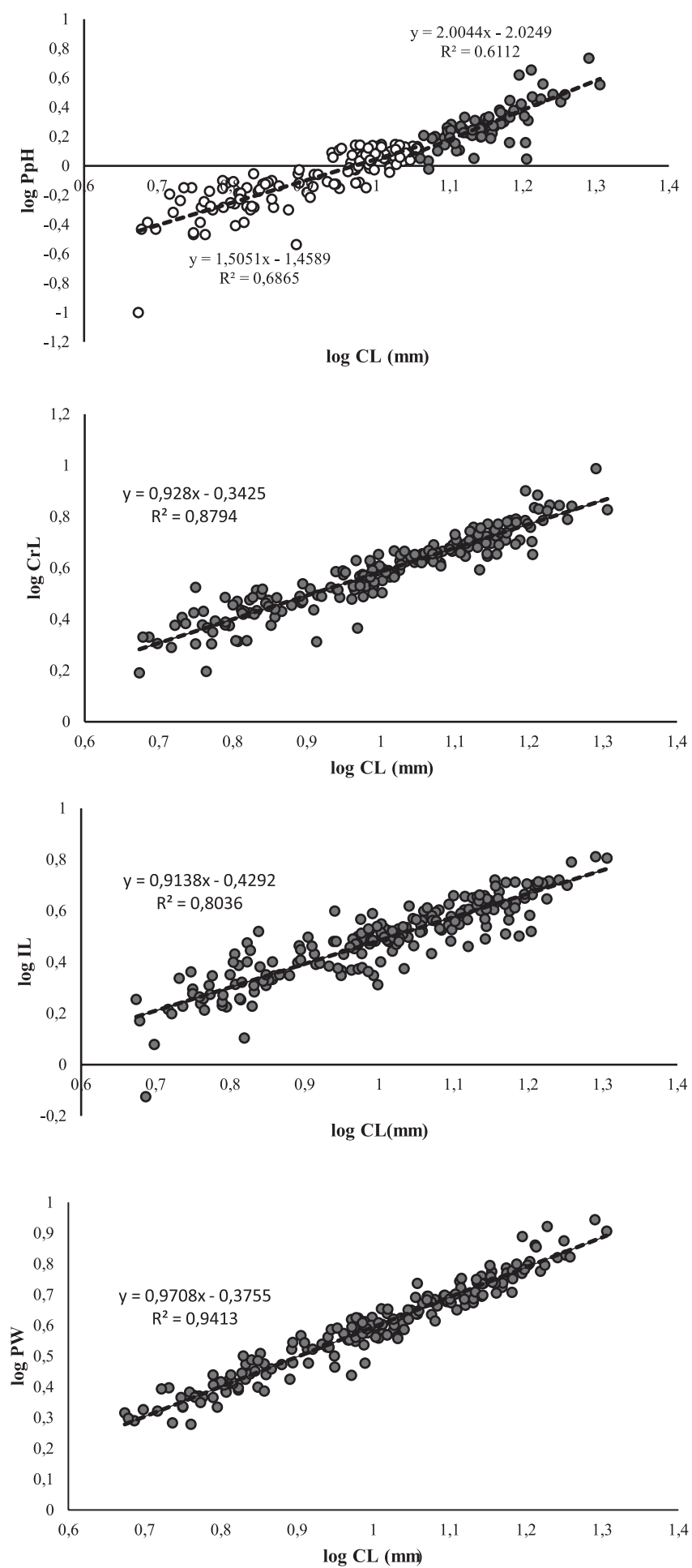

Figure 5. Estimation of the size at onset of morphological sexual maturity of Macrobrachium iheringi (Ortmann, 1897) females. The estimated size is the carapace length (CL) of the smallest adult individual, obtained after the distinction of juvenile (open circles) and adult (black circles) equations. PW $=$ pleura width, $\mathrm{AL}=$ abdomen length, $\mathrm{IL}=$ ischium length, $\mathrm{ML}=$ merus length, $\mathrm{CrL}=$ carpus length, $\mathrm{PpL}=$ propodus length, $\mathrm{DcL}=$ dactyl length and $\mathrm{PpH}=$ propodus height. 
Table 1. Scores of the nine morphometric measurements of the first two axes of the principal component analysis. The structure with the highest score in $\mathrm{PC} 1$ is shown in bold.

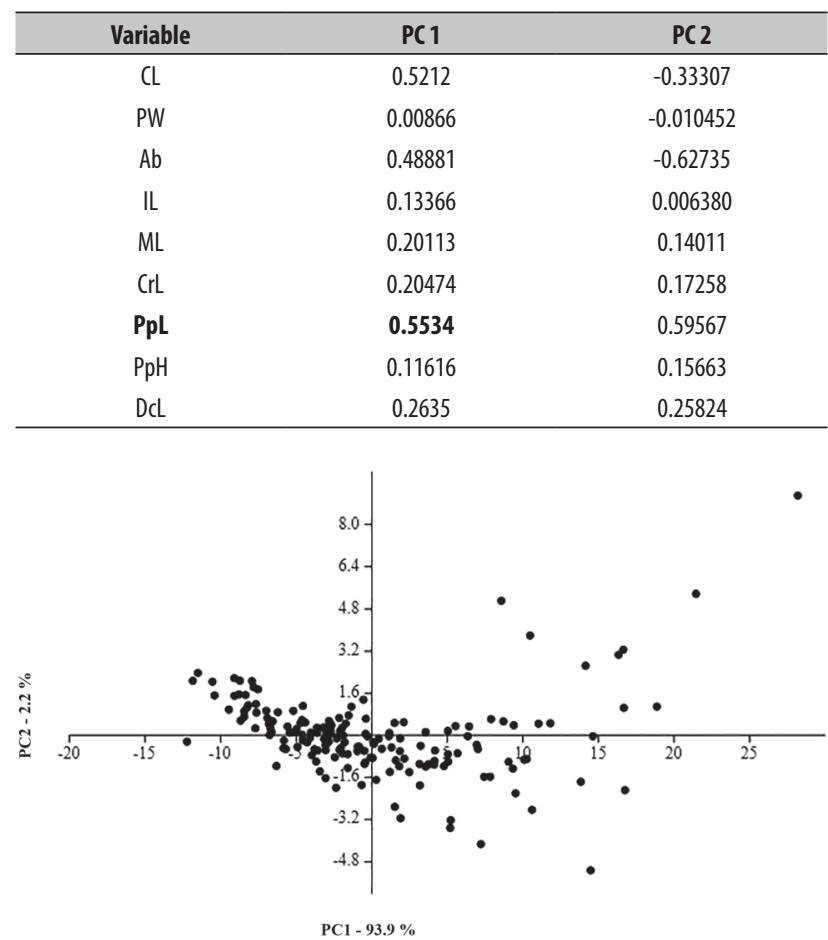

Figure 6. Projection scores of first and second principal components, generated with the principal components analysis of Macrobrachium iheringi (Ortmann, 1897) males' morphometric data.

July 1993 to June 1994, there was a higher abundance of ovigerous females in November and December, and a lower from January to March (Fig. 8).

Fecundity varied from 57 to 107 eggs, in females with $\mathrm{CL}$ ranging from 51 to $56 \mathrm{~mm}$, with a mean of 76 eggs per female. There was a significant positive relationship between $C L$ and fecundity ( $p=0.005, F=11.2$, df $=13$ ) (Fig. 9).

Egg size varied with development. In the early stage, width was 1.41-1.61 mm and length was $2.02-2.2 \mathrm{~mm}$, with a mean width of $1.49 \mathrm{~mm}$ and mean length of $2.13 \mathrm{~mm}$. Egg volume ranged from 2.22 to $2.9 \mathrm{~mm}^{3}$, with a mean of $2.48 \mathrm{~mm}^{3}$. In the late stage, egg width was 1.5-1.66 mm, and length was 2.11-2.24 mm, with a mean width of $1.59 \mathrm{~mm}$ and mean length of $2.19 \mathrm{~mm}$. Egg volume in the late stage ranged from 2.55 to $3.14 \mathrm{~mm}^{3}$, with mean of $2.91 \mathrm{~mm}^{3}$. There was an increase of nearly $17 \%$ in egg volume between the early and late stages.

A time series analysis (Cross-correlation) of the period 1993/1994 indicated a positive correlation ("lag -2") between pluviosity and number of ovigerous females (Fig. 10A), meaning that two months after pluviosity increased there was a higher abundance of ovigerous females. A positive correlation between temperature and ovigerous females ("lag 0") was also observed (Fig. 10B), indicating that abundance increased with temperature. However, there was no correlation between the abundance of ovigerous females and environmental factors in 1991/1992.
Table 2. Macrobrachium iheringi (Ortmann, 1897). Results of covariance analysis (ANCOVA). $(J)$ juveniles and (A) adults.

\begin{tabular}{|c|c|c|c|c|}
\hline Relationship & Group & Coefficient (log) & $\mathbf{F}$ & $\mathbf{P}$ \\
\hline \multirow[t]{4}{*}{$\mathrm{PW}$ vs $\mathrm{CL}$} & Male J vs A & $a$ & - & - \\
\hline & & $b$ & 13.63 & $<0.001^{*}$ \\
\hline & Female J vs A & $\mathrm{a}$ & 0.22 & 0.638 \\
\hline & & $b$ & 1.10 & 0.296 \\
\hline \multirow[t]{4}{*}{$\mathrm{AL}$ vs $\mathrm{CL}$} & Male J vs A & $\mathrm{a}$ & - & - \\
\hline & & b & 31.32 & $<0.001^{*}$ \\
\hline & Female J vs A & $a$ & - & - \\
\hline & & $b$ & 10.24 & $<0.001^{*}$ \\
\hline \multirow[t]{4}{*}{ IL vs CL } & Male J vs A & $\mathrm{a}$ & 5.42 & $0.021^{*}$ \\
\hline & & b & 1.31 & 0.254 \\
\hline & Female J vs A & $\mathrm{a}$ & 0.38 & 0.540 \\
\hline & & b & 1.17 & 0.282 \\
\hline \multirow[t]{4}{*}{$\mathrm{ML}$ vs $\mathrm{CL}$} & Male J vs A & $\mathrm{a}$ & - & - \\
\hline & & b & 10.93 & $<0.001^{*}$ \\
\hline & Female J vs A & $\mathrm{a}$ & 0.25 & 0.618 \\
\hline & & $\mathrm{b}$ & 0.99 & 0.32 \\
\hline \multirow[t]{4}{*}{ CrL vs $\mathrm{CL}$} & Male J vs A & $\mathrm{a}$ & - & - \\
\hline & & b & 8.75 & $<0.001^{*}$ \\
\hline & Female J vs A & $\mathrm{a}$ & 0.31 & 0.578 \\
\hline & & b & 0.24 & 0.632 \\
\hline \multirow[t]{4}{*}{ PpL vs CL } & Male J vs A & $\mathrm{a}$ & - & - \\
\hline & & b & 15.88 & $<0.001^{*}$ \\
\hline & Female J vs A & $\mathrm{a}$ & - & - \\
\hline & & b & 4.33 & $0.039^{*}$ \\
\hline \multirow[t]{4}{*}{$\mathrm{PpH}$ vs CL } & Male J vs A & $\mathrm{a}$ & - & - \\
\hline & & $b$ & 18.77 & $<0.001^{*}$ \\
\hline & Female J vs A & $\mathrm{a}$ & - & - \\
\hline & & b & 12.16 & $<0.001^{*}$ \\
\hline \multirow[t]{4}{*}{$\mathrm{DL}$ vs CL } & Male J vs A & $\mathrm{a}$ & - & - \\
\hline & & b & 28.20 & $<0.001^{*}$ \\
\hline & Female J vs A & $\mathrm{a}$ & - & - \\
\hline & & $b$ & 5.04 & $0.026^{*}$ \\
\hline
\end{tabular}

During the first sampling period undifferentiated juveniles were found in December 1991, and March-June 1992 (Fig. 7), whereas in the second period they were found in July-October 1993 and January-June 1994 (Fig. 8). There was a positive correlation ("lag 1") between pluviosity and number of undifferentiated juveniles in 1991/1992 (Fig. 11A); thus, one month after pluviosity increased there was a higher abundance of juveniles. There was also a negative correlation ("lag - 3 ") between temperature and undifferentiated juveniles in 1993/1994 (Fig. 11B); three months after a rise in temperature their abundance decreased.

\section{DISCUSSION}

Previous studies (Mantelatto \& Barbosa, 2005; Mossolin \& Bueno, 2002; Pantaleão et al., 2012) indicated the second pair of chelipeds as good indicators of morphological sexual maturity. In this study, we observed the second pair of chelipeds and the second abdominal pleura as indicators of juveniles and adults of $M$. iheringi, corroborating the previously mentioned studies. The pleura width is commonly used as an indicator of mor- 
Pap. Avulsos Zool., 2019; v.59: e20195908

Nogueira, C.S. et al: Relative growth and dynamics of Macrobrachium iheringi

$8 / 13$

1991

1992

6 July

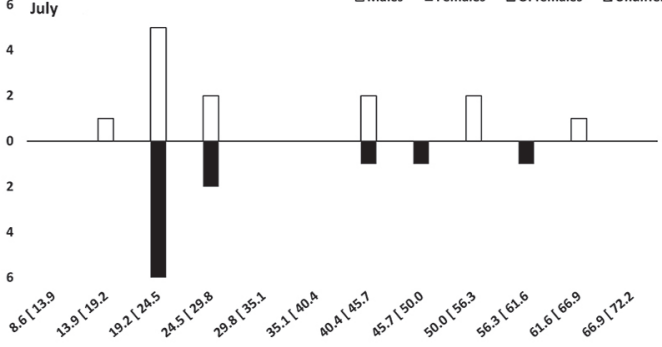

9 August
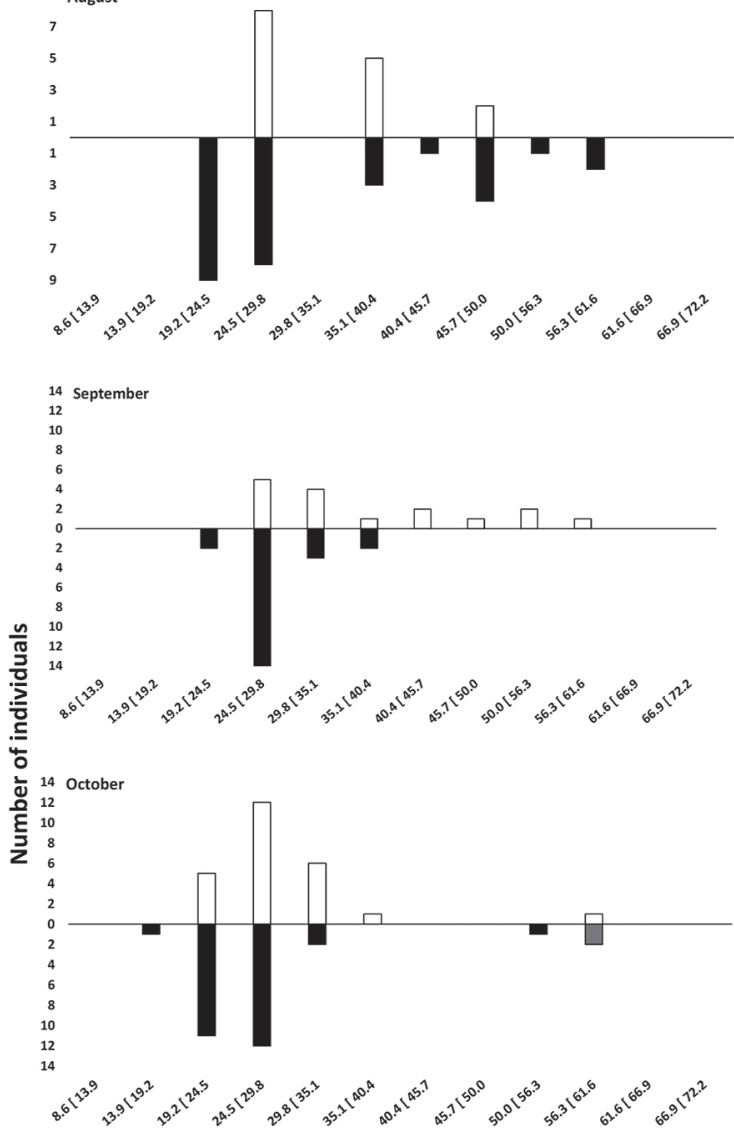

12 November

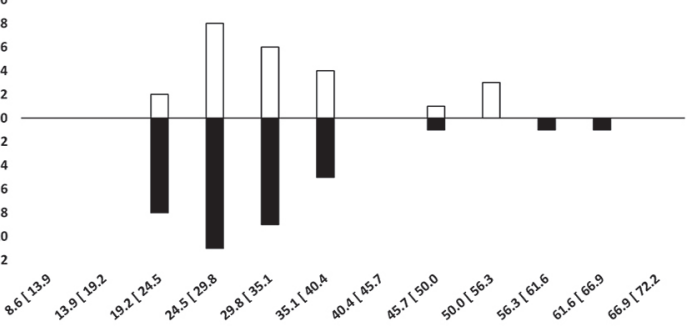

12 December

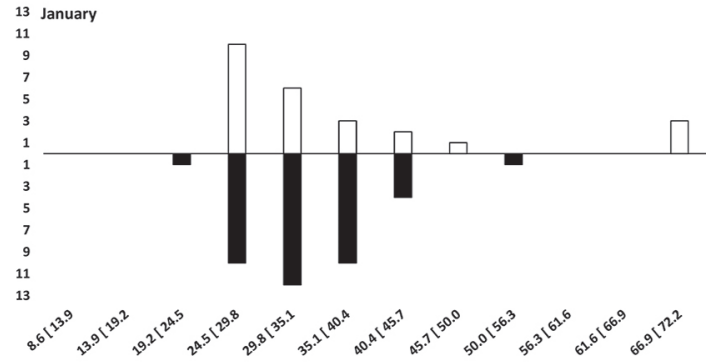

9 February

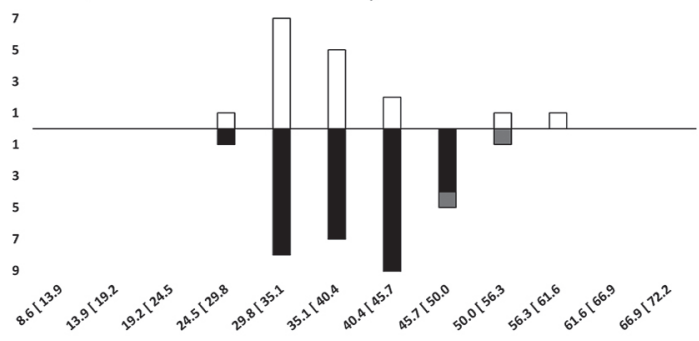

9 March
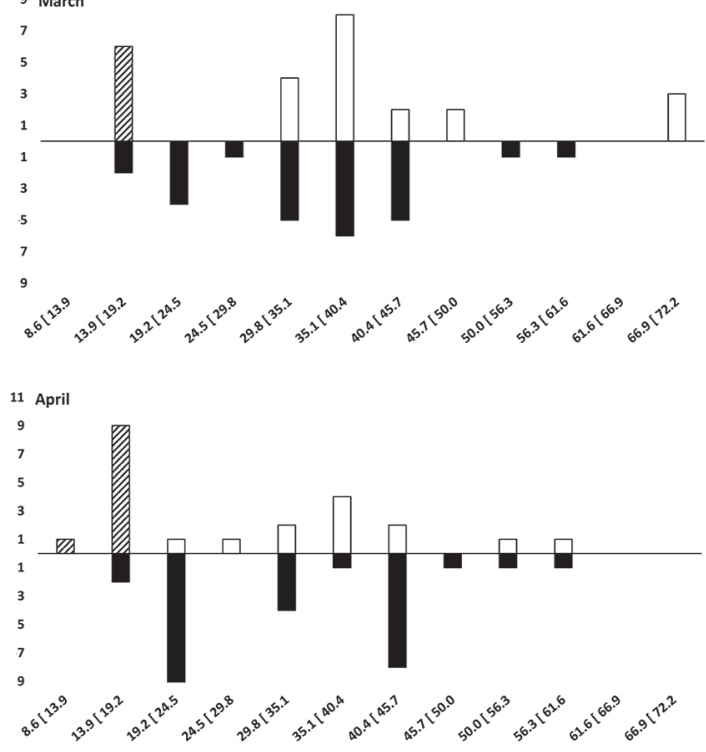

6 May

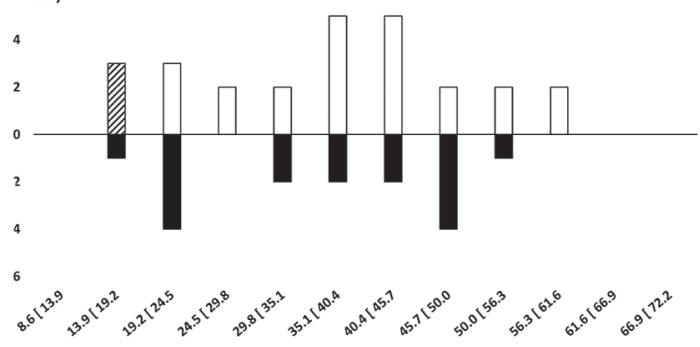

5 June

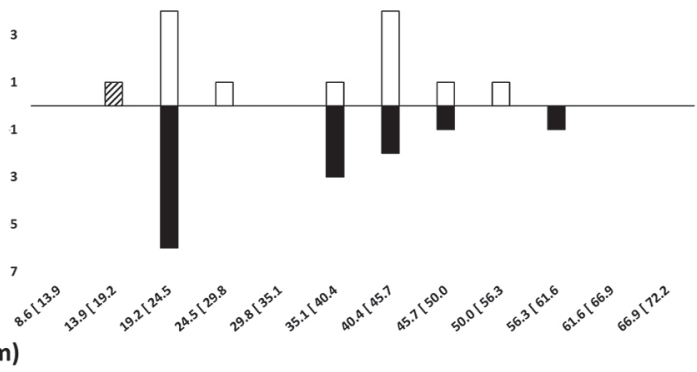

Figure 7. Monthly distribution of individuals of Macrobrachium iheringi (Ortmann, 1897) by size classes, captured from July 1991 to June 1992. 
1993

1994
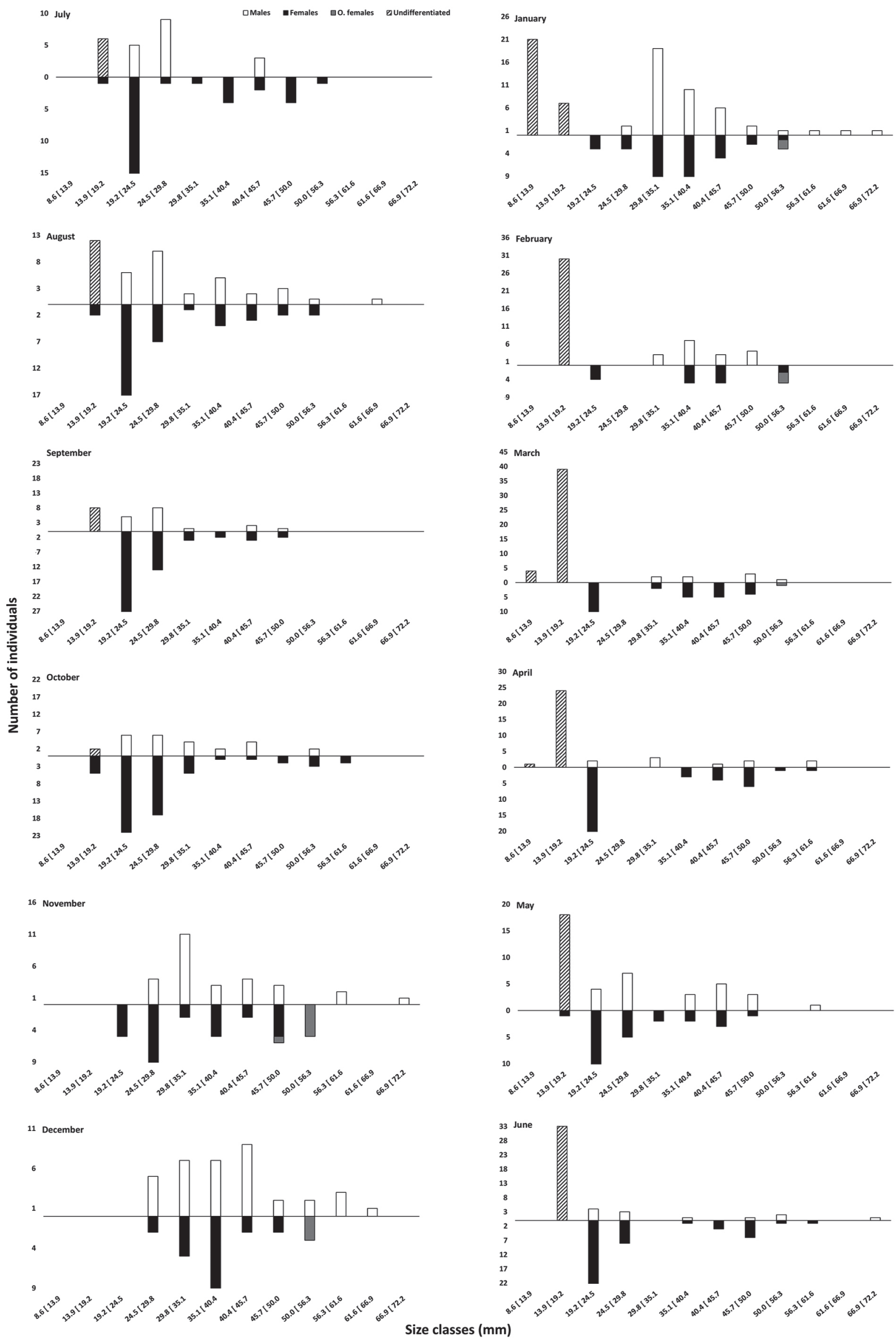

Figure 8. Monthly distribution of individuals of Macrobrachium iheringi (Ortmann, 1897) by size classes, captured from July 1993 to June 1994. 


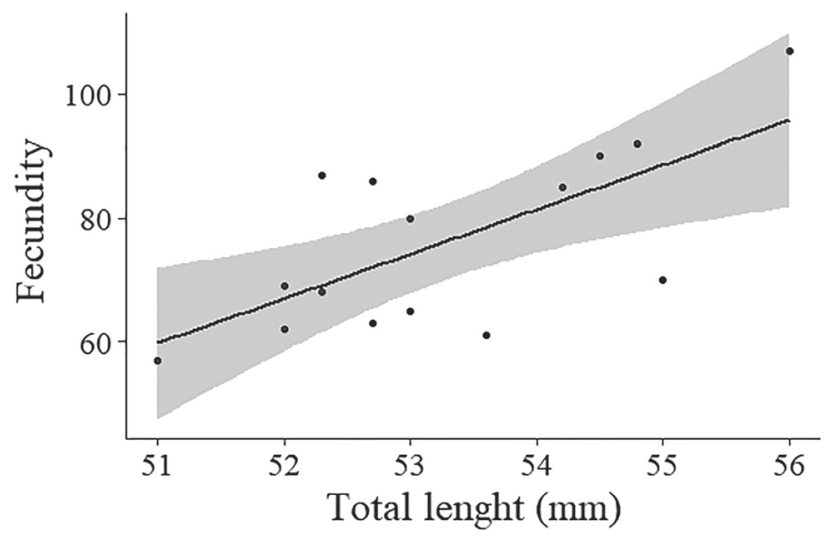

Figure 9. Macrobrachium iheringi (Ortmann, 1897). Relationship between fecundity and total length of females.

phological sexual maturity for females; however, the ANCOVA results showed no difference in the size of this structure among the demographic classes of the studied population. Therefore, cheliped was used as an indicator of morphological maturity in both sexes.

Based on the relative growth of males, different growth patterns were observed from juveniles to adults. Almost all analyzed morphometric relationships differed between juveniles and adults, being allometric negative in juveniles and allometric positive or isometric in adults. With the exception of the relations $\mathrm{AL}$ vs $\mathrm{CL}, \mathrm{PW}$ vs $\mathrm{CL}$ and $\mathrm{PpH}$ vs $\mathrm{CL}$, where both classes presented during development negative allometry in the first two relations and positive allometry in the last relation. These results emphasize the different energy investments during development. Juveniles invest in somatic growth to achieve sexual maturity and to be able to reproduce, while adults invest more in structures related to reproductive success. For example, males need to compete for females with the help of chelipeds (Correa \& Thiel, 2003; Hartnoll, 1978, 1982). To females, pereopods relationships were similar, as described above, since almost all relationships were identical among demographic classes. As the second pereopod can have several functions in these prawns, such as feeding and sexual and agonistic behaviors, this structure may develop in a similar way, presenting different functionalities in different demographic classes (Karplus et al., 1992; Nagamine \& Knight, 1980; Volpato \& Hoshino, 1984; Valenti et al., 1989).

In abdominal structures, the development of both pleura and abdomen, was shown as negative allometric in the two phases of life, therefore, these structures are

$1993 / 1994$
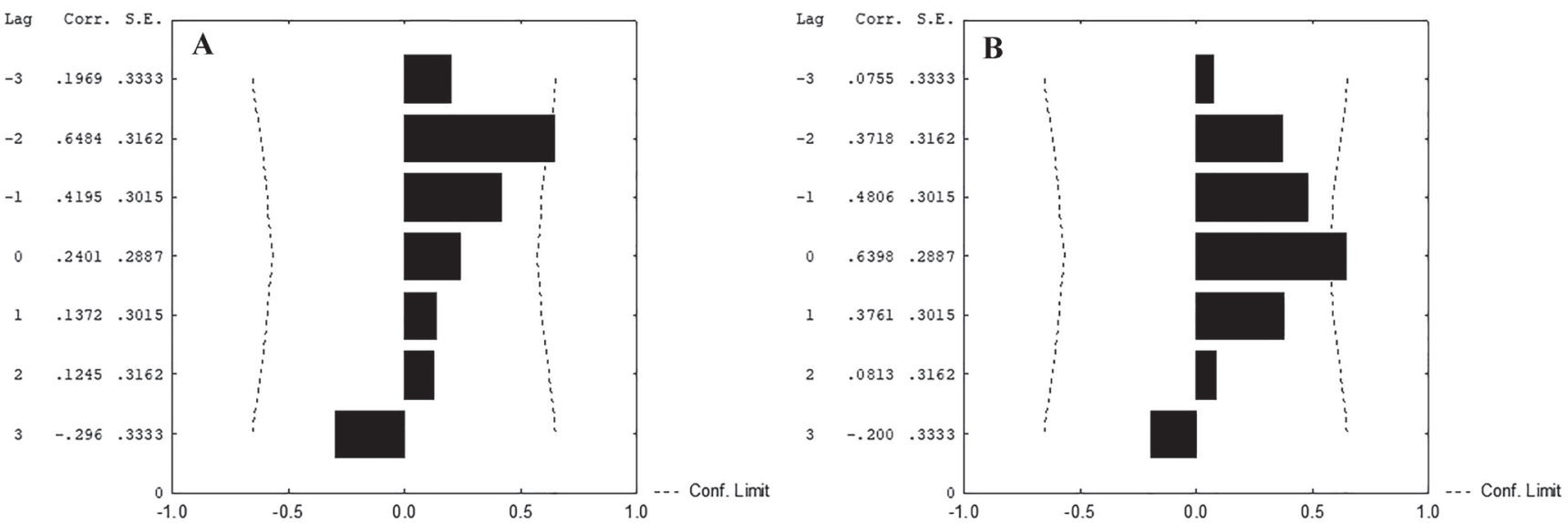

Figure 10. Macrobrachium iheringi (Ortmann, 1897). Time series analysis of ovigerous females and (A) rainfall $(\mathrm{mm})$ and $(B)$ temperature $\left({ }^{\circ} \mathrm{C}\right)$ from July 1993 to June 1994 in Botucatu, Brazil. Lag = time; Corr = correlation value; S.E. = standard error; Conf. Limit = confidence limit.
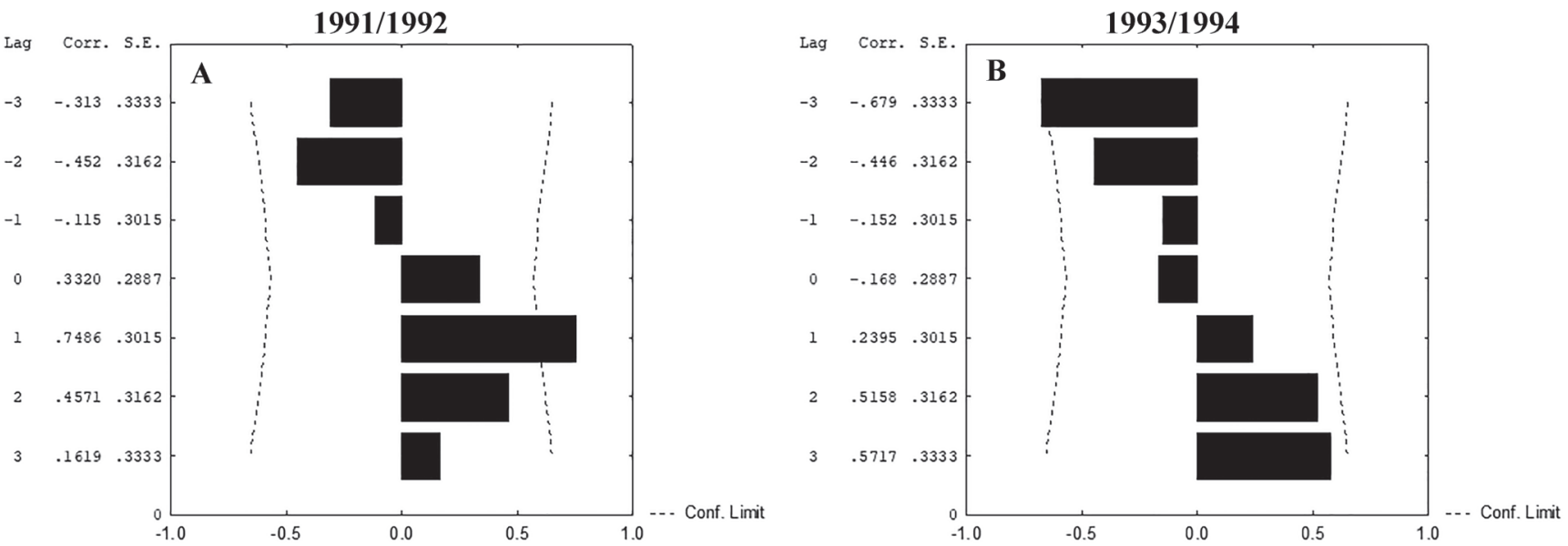

Figure 11. Macrobrachium iheringi (Ortmann, 1897). Time series analysis of undifferentiated individuals and (A) rainfall (mm) from July 1991 to June 1992 and (B) temperature ( ${ }^{\circ} \mathrm{C}$ ) from July 1993 to June 1994 in Botucatu, Brazil. Lag = time; Corr = correlation value; S.E. = standard error; Conf. Limit = confidence limit. 
Table 3. Macrobrachium iheringi (Ortmann, 1897). Regression analysis of morphometric data. CL was used as the independent variable. (AM) adult males, (JM) juvenile males, (AF) adult females and (JF) juvenile females.

\begin{tabular}{|c|c|c|c|c|c|c|c|c|}
\hline Relation & Sex & $\mathrm{N}$ & $a$ & $b$ & $r^{2}$ & $T(\mathrm{~b}=1)$ & $p$ & Allometry \\
\hline \multirow[t]{3}{*}{ PW vs CL } & AM & 45 & -0.0511 & 0.6541 & 0.6815 & -2.974 & $<0.001$ & - \\
\hline & $J M$ & 124 & -0.2442 & 0.8168 & 0.787 & 2.021 & $<0.001$ & - \\
\hline & $\mathrm{AF}$ and JF & 190 & -0.3755 & 0.9708 & 0.9413 & 1.649 & $<0.001$ & - \\
\hline \multirow[t]{4}{*}{$\mathrm{AL}$ vs $\mathrm{CL}$} & $\mathrm{AM}$ & 46 & 0.5973 & 0.5902 & 0.7819 & -7.269 & $<0.001$ & - \\
\hline & $J M$ & 125 & 0.4362 & 0.7241 & 0.8988 & -7.633 & $<0.001$ & - \\
\hline & $A F$ & 76 & 0.3742 & 0.7832 & 0.8301 & -4.696 & $<0.001$ & - \\
\hline & $\mathrm{JF}$ & 117 & 0.4094 & 0.7487 & 0.8832 & -6.096 & $<0.001$ & - \\
\hline \multirow[t]{3}{*}{ IL vs CL } & AM & 46 & -0.612 & 1.0496 & 0.6237 & 1.622 & 0.53 & $=$ \\
\hline & $J M$ & 125 & -0.3661 & 0.8649 & 0.6754 & -1.687 & $<0.01$ & - \\
\hline & $\mathrm{AF}$ and JF & 193 & -0.4292 & 0.9138 & 0.8036 & 2.638 & $<0.001$ & - \\
\hline \multirow[t]{3}{*}{$\mathrm{ML}$ vs $\mathrm{CL}$} & $\mathrm{AM}$ & 46 & -0.8612 & 1.347 & 0.7449 & 2.764 & 0.08 & $=$ \\
\hline & $J M$ & 125 & -0.2875 & 0.8562 & 0.7262 & 2.611 & $<0.01$ & - \\
\hline & $\mathrm{AF}$ and JF & 193 & -0.3968 & 0.967 & 0.8799 & 1.275 & $<0.001$ & - \\
\hline \multirow[t]{3}{*}{ CrL vs CL } & AM & 46 & -0.7699 & 1.2753 & 0.716 & 2.788 & 0.09 & $=$ \\
\hline & JM & 125 & -0.2832 & 0.8576 & 0.6725 & 2.876 & $<0.01$ & - \\
\hline & $\mathrm{AF}$ and JF & 193 & -0.3425 & 0.928 & 0.8794 & 2.894 & $<0.001$ & $=$ \\
\hline \multirow[t]{4}{*}{ PpL vs CL } & AM & 46 & -0.8167 & 1.5944 & 0.7428 & 2.729 & $<0.05$ & + \\
\hline & $J M$ & 125 & -0.233 & 1.0632 & 0.7851 & 5.254 & 0.06 & $=$ \\
\hline & $\mathrm{AF}$ & 76 & -0.7152 & 1.527 & 0.7174 & 7.670 & $<0.01$ & + \\
\hline & $\mathrm{JF}$ & 117 & -0.3047 & 1.144 & 0.8131 & 2.255 & 0.09 & $=$ \\
\hline \multirow[t]{4}{*}{ PpH vs CL } & AM & 46 & -2.0542 & 1.9993 & 0.6914 & 4.604 & $<0.01$ & + \\
\hline & $\mathrm{JM}$ & 125 & -1.3507 & 1.3937 & 0.7108 & 15.685 & $<0.001$ & + \\
\hline & AF & 76 & -0.462 & 1.034 & 0.6409 & 5.580 & $<0.001$ & + \\
\hline & $\mathrm{JF}$ & 117 & -0.301 & 0.8808 & 0.746 & 19.460 & $<0.001$ & - \\
\hline \multirow[t]{4}{*}{ DCL vs CL } & AM & 46 & -1.2826 & 1.7107 & 0.8377 & 4.273 & $<0.001$ & + \\
\hline & $\mathrm{JM}$ & 125 & -0.555 & 1.0692 & 0.7564 & 7.892 & 0.12 & $=$ \\
\hline & AF & 76 & -0.7152 & 1.527 & 0.7174 & 2.859 & 0.12 & $=$ \\
\hline & $\mathrm{JF}$ & 117 & -0.3047 & 1.1443 & 0.8131 & 8.15 & 0.21 & $=$ \\
\hline
\end{tabular}

developing at the same rhythm independent of phase of life. Mantelatto \& Barbosa (2005) found a similar result in their study with M. brasiliense (Heller, 1862) and hypothesized that the pleura would not develop much due to its abbreviated larval development, which also occurs in $M$. iheringi. Due to the increase of the embrionic stages that occur within the eggs, and because females have a small number of eggs, the pleura need not be as developed as in species with longer larval stages (Mantelatto \& Barbosa, 2005).

The reproductive period was considered seasonal as the presence of ovigerous females occurred only in the warmer months. In the second sampling period, the presence of ovigerous females was related with higher pluviosity and higher temperatures, their abundance increased in rainy periods and when water temperature reached $20^{\circ} \mathrm{C}$. According to Alekhnovich \& Kulesh (2001), the occurrence of reproduction when temperature reaches between 18 and $20^{\circ} \mathrm{C}$ is apparently a general pattern for Macrobrachium. Reproductive peaks after an increase in pluviosity and temperature were also observed in other species of the genus, M. olfersii (Wiegmann, 1836), M. hainanense (Parisi, 1919) and M. jelskii (Miers, 1877) (Mossolin \& Bueno, 2002; Mantel \& Dudgeon, 2005; Mossolin et al., 2013; Soares et al., 2015; Rocha \& Barbosa, 2017). The recruitment of undifferentiated juveniles occurs in the months after the appearance of ovigerous
Table 4. Total number Macrobrachium iheringi (Ortmann, 1897) males, females and undifferentiated juveniles per size class $(\mathrm{mm})$, and the sex ratio $(\mathrm{M}: \mathrm{F})$. The chi-square value $\left(\mathrm{X}^{2}\right)$ indicates the comparison with the expected 1:1 ratio, and $P$ is the statistical significance.

\begin{tabular}{ccccccc}
\hline Size classes & Males & Females & $\begin{array}{c}\text { Undifferentiated } \\
\text { Juveniles }\end{array}$ & M:F & $\mathbf{X}^{2}$ & $\mathbf{P}$ \\
\hline $8.6[13.9$ & 0 & 0 & 27 & - & - & - \\
$13.9[19.2$ & 1 & 15 & 198 & $1: 15$ & 12.25 & $>0.001$ \\
$19.2[24.5$ & 58 & 247 & 0 & $1: 3.31$ & 71.82 & $>0.001$ \\
$24.5[29.8$ & 112 & 139 & 0 & $1: 1.24$ & 2.90 & 0.088 \\
$29.8[35.1$ & 98 & 87 & 0 & $1: 0.88$ & 0.65 & 0.419 \\
$35.1[40.4$ & 80 & 97 & 0 & $1: 1.21$ & 1.63 & 0.201 \\
$40.4[45.7$ & 60 & 74 & 0 & $1: 1.23$ & 1.46 & 0.227 \\
$45.7[50.0$ & 34 & 54 & 0 & $1: 1.58$ & 4.55 & $>0.05$ \\
$50.0[56.3$ & 21 & 32 & 0 & $1: 1.52$ & 2.28 & 0.131 \\
$56.3[61.6$ & 15 & 13 & 0 & $1: 0.86$ & 0.14 & 0.705 \\
$61.6[66.9$ & 6 & 1 & 0 & $1: 0.16$ & 3.57 & 0.06 \\
$66.9[72.2$ & 9 & 0 & 0 & $9: 00$ & 9.00 & $>0.05$ \\
\hline Total & 494 & 759 & 225 & $1: 1.42$ & 36.81 & $>0.001$ \\
\hline
\end{tabular}

females, therefore, it is suggested that the reproductive period of $M$. iheringi is seasonal.

Regarding fecundity, $M$. iheringi had a lower amount of eggs but they were larger than in other species of the genus (e.g., M. potiuna (Müller, 1880) and M. brasiliense) (Nazari et al., 2003; Oliveira et al., 2017), reflecting the reproductive strategy of this species. As $M$. iheringi has an abbreviated larval cycle, the larval development occurs mostly inside the eggs and larvae hatch in an advanced stage (Bueno \& Rodrigues, 1995; Magalhães \& Walker, 1988). When compared to other species of Macrobrachium that have abbreviated larval development, we observe similar results: $M$. brasiliense has on average 33 eggs per female, with fecundity varying between 8 and 116 eggs, and in M. potiuna, fecundity is 35 eggs on average and ranges from 19 to 65 eggs. In addition, for $M$. iheringi, egg size was similar to those of M. potiuna, which were $1.41 \mathrm{~mm}$ wide and $2.17 \mathrm{~mm}$ long (Nazari et al., 2003; Oliveira et al., 2017). Even though the fecundity of $M$. iheringi was twice that of $M$. brasiliense and M. potiuna; however, it can still be considered low and similar to other Macrobrachium species with abbreviated larval cycle, considering that species with extended larval cycle can carry 1,500 eggs on average, as observed in M. olfersii and M. amazonicum (Nazari et al., 2003; Silva et al., 2004).

According to Bauer (2003), in crustacean species that display mate guarding behavior, males are bigger than females, due to agonistic interactions that this behavior induces. In the population studied here, males reached a larger size than females, following the pattern shown by most caridean prawns with mate guarding behavior (Bauer, 2003; Gualberto et al., 2012). It may be possible that these morphological variations occur due to genetic variations between populations and different environmental conditions, which may stimulate differential growth between sexes (Weiss et al., 2015).

The sex ratio observed in the studied population was skewed towards females, which is a common pattern 
in caridean prawns and in Macrobrachium spp., as noted in studies of Macrobrachium acanthurus (Wiegmann, 1836) (Román-Contreras \& Campos-Lince, 1993), M. amazonicum (Montoya, 2003), M. brasiliense (Mantelatto \& Barbosa, 2005) and M. jelskii (Barros-Alves et al., 2012). This variation may be influenced by differences in size, mortality, birth rates between males and females, ecdysis frequency, larval dispersion, and differential migration. The reproductive pattern of $M$. iheringi can be reflected in the sex ratio, since, in species that display mating guarding behavior, sexual deviance for females is usually greater. (Bauer, 2003; Wilson \& Pianka, 1963; Botelho et al., 2001).

Information on M. iheringi is scarce when compared to other species of the genus. Unlike several Macrobrachium species of Brazil, M. iheringi is not cultivated, and it also differs regarding its life cycle patterns. Since this prawn is part of a unique group in which the life cycle occurs exclusively in freshwater, studies on the biology of this species are important to better comprehend their adaptations to this environment. Our results provide important information on its population structure, relative growth in juveniles and adults, and size at maturity. Also, studies on other forms of sexual maturity, such as gonadal, physiological, and functional, may also help to better understand this species reproductive cycle.

\section{ACKNOWLEDGMENTS}

The authors are thankful to CNPq (Conselho Nacional de Deenvolvimento Cientifico e Tecnológico) for financial support during field work. All sampling in this study has been conducted in compliance with current applicable state and federal laws. We are also thankful to the anonymous reviewers and to Bernard Sainte-Marie for the contributions and improvement of our manuscript.

\section{REFERENCES}

Alekhnovich, A.V. \& Kulesh, V.F. 2001. Variation in the parameters of the life cycle in prawns of the genus Macrobrachium Bate (Crustacea, Palaemonidae). Russian Journal of Ecology, 32: 420-424.

Barros-Alves, S.D.P.; Almeida, A.C.; Fransozo, V.; Alves, D.F.R.; Silva, J.C.D. \& Cobo, V.J. 2012. Population biology of shrimp Macrobrachium jelskii (Miers, 1778) (Decapoda, Palaemonoidea) at the Grande River at northwest of the state of Minas Gerais, Brazil. Acta Limnologica Brasiliensia, 24(3): 266-275.

Bauer, R.T. 2003. Remarkable shrimps: natural history and adaptations of the carideans. Norman, University of Oklahoma Press.

Botelho, E.R.0.; Santos, M.C.F. \& Souza, J.R.B. 2001. Aspectos populacionais do Guaiamum, Cardisoma guanhumi Latreille, 1825, do estuário do Rio Una (Pernambuco - Brasil). Boletim Técnico Científico (EPENE, 9(1): 123-146.

Bueno, S.L.D.S. \& Rodrigues, S.D.A. 1995. Abbreviated larval development of the freshwater prawn, Macrobrachium iheringi (Ortmann, 1897) (Decapoda, Palaemonidae), reared in the laboratory. Crustaceana, 68(8): 665-686.

Coelho, P.A. \& Ramos-Porto, M. 1984. Camarões de água doce do Brasil: distribuição geográfica. Revista Brasileira de Zoologia, 2(6): 405-410.
Correa, C. \& Thiel, M. 2003. Mating systems in caridean shrimp (Decapoda: (aridea) and their evolutionary consequences for sexual dimorphism and reproductive biology. Revista Chilena de Historia Natural, 76(2): 187-203.

Favaretto, L. 1973. Aspectos fisiológicos do camarão de água doce Macrobrachium iheringi (Ortmann, 1897), (Crustacea - Decapoda Palaemonidae). (Doctoral Thesis). Universidade de São Paulo, Ribeirão Preto, São Paulo.

Fransozo, A.; Rodrigues, F.D.; Freire, F.A.M. \& Costa, R.C. 2004. Reproductive biology of the prawn Macrobrachium iheringi (Ortmann, 1897) (Decapoda, Caridea, Palaemonidae) in Botucatu region, São Paulo, Brazil. Nauplius, 12(2): 119-126.

García-Guerrero, M.U. \& Hendrickx, M.E. 2009. External description of the embryonic development of the prawn, Macrobrachium americanum Bate, 1868 (Decapoda, Palaemonidae) based on the staging method. Crustaceana, 82(11): 1413-1422.

Gomes-Correa, M.M. 1977. Palaemonideos do Brasil (Crustacea, Decapoda, Natantia). (Masters Dissertation). Rio de Janeiro, Universidade Federal do Rio de Janeiro.

Gualberto, T.L.; Almeida, L.0. \& Menin, M. 2012. Population structure, fecundity and ecological aspects of freshwater shrimp species (Decapoda, Palaemonidae) of an urban forest fragment in central Amazonia, Brazil. Crustaceana, 85(10): 1205-1219.

Hartnoll, R.G. 1974. Variation in growth pattern between some secondary sexual characters in crabs (Decapoda Brachyura). Crustaceana, 27(2): 131-136.

Hartnoll, R.G. 1978. The determination of relative growth in crustacea. Crustaceana, 34(3): 281-293.

Hartnoll, R.G. 1982. Growth. In: Bliss, D.E. The Biology of Crustacea. Embriology, Morphology and Genetics. New York, Academic Press.

Hirose, G.L.; Fransozo, V.; Tropea, C.; López-Greco, L.S. \& Negreiros-Fransozo, M.L. 2013. Comparison of body size, relative growth and size at on set maturity of Uca uruguayensis (Crustacea, Decapoda: Ocypodidae) from different latitudes in the south-western Atlantic. Journal of the Marine Biological Association of the United Kingdom, 93(3): 781-788.

Karplus, I.; Hulata, G.; Ovadia, D. \& Jaffe, R. 1992. Social control of growth in Macrobrachium rosenbergii. III. The role of claws in bull-runt interactions. Aquaculture, 105(3-4): 281-296.

Kuris, A.M.; Ra'anan, Z.; Sagi, A.\& Cohen, D. 1987. Morphotypic differentiation of male Malaysian giant prawns, Macrobrachium rosenbergii. Journal of Crustacean Biology, 7(2): 219-237.

Lobão, V.L.; Musto, M.R.Z.N.; Rojas, N.E.T.; Lace, M. \& Magalhães, M.D. 1986. Estudo populacional de Macrobrachium iheringi (Ortmann, 1897) (Decapoda, Palaemonidae) do Rio Buava, SP. Boletim Institucional de Pesca, 13(2).

Magalhães, C. \& Walker, I. 1988. Larval development and ecological distribution of central amazonian palemonid shrimps (Decapoda: Caridea). Crustaceana, 55(3): 279-292.

Magalhães, C.; Campos, M.R.; Collins, P.A. \& Mantelatto, F.L. 2016. Diversity, distribution and conservation of freshwater crabs and shrimps in South America. In: Kawai, T.; Cumberlidge, N. (Eds). A global overview of the conservation of freshwater decapod crustaceans. Cham Springer. p. 303-322.

Mantel, S.K. \& Dudgeon, D. 2005. Reproduction and sexual dimorphism of the palaemonid shrimp Macrobrachium hainanse in Hong Kong streams. Journal of Crustacean Biology, 25(3): 450-459.

Mantelatto, F.L.; Pileggi, L.G.; Magalhães, C.; Carvalho, F.L.; Rocha, S.S.; Mossolin, E.C.; Rossi, N. \& Bueno, S.L.S. 2016. Avaliação dos Camarões Palemonídeos (Decapoda: Palaemonidae). In: Pinheiro, M.A.A. \& Boos, H. Livro Vermelho dos Crustáceos do Brasil: Avaliação 2010-2014. Porto Alegre, Sociedade Brasileira de Carcinologia. p. 252-260. 
Mantelatto, F.L.M. \& Barbosa, L.R. 2005. Population structure and relative growth of freshwater prawn Macrobrachium brasiliense (Decapoda, Palaemonidae) from São Paulo State, Brazil. Acta Limnologica Brasiliensia, 17(3): 245-255

Melo, G.A.S. 2003. Manual de Identificação dos Crustacea Decapoda de água doce do Brasil. São Paulo, São Paulo, Editora Loyola.

Montoya, J.V. 2003. Freshwater shrimps of the Genus Macrobrachium Associated with roots of Eichhornia crassipes (Water Hyacinth) in the Orinoco Delta (Venezuela). Caribbean Journal of Science, 39(1): 155-159.

Moraes-Riodades, P. \& Valenti, W.C. 2002. Crescimento relativo do camarão canela Macrobrachium amazonicum (Heller) (Crustacea, Decapoda, Palaemonidae) em viveiros. Revista Brasileira de Zoologia, 19(4): 1181-1214.

Moraes-Riodades, P.M.C. \& Valenti, W.C. 2004. Morphotypes in male Amazon river prawns, Macrobrachium amazonicum. Aquaculture, 236(1-4): 297-307.

Mossolin, E.C. \& Bueno, S.L. 2002. Reproductive biology of Macrobrachium olfersii (Decapoda, Palaemonidae) in São Sebastião, Brazil. Journal of Crustacean Biology, 22(2): 367-376.

Mossolin, E.C.; Peiró, D.F.; Rossingnoli, M.O.; Rajab, L.P. \& Mantelatto, F.L.M. 2013. Population and reproductive features of the freshwater shrimp Macrobrachium jelskii (Miers, 1877) from São Paulo State, Brazil. Acta Scientiarium Biological Sciences, 35(3): 429-436.

Nagamine, C.M. \& Knight, A.W. 1980. Development, maturation, and function of some sexually dimorphic structures of the Malaysian prawn, Macrobrachium rosenbergii (De Man) (Decapoda, Palaemonidae). Crustaceana, 39(2): 141-152.

Nazari, E.M.; Simões-Costa, M.S.; Müller, Y.M.R.; Ammar, D. \& Dias, M. 2003. Comparisons of fecundity, egg size, and egg mass volume of the freshwater prawns Macrobrachium potiuna and Macrobrachium olfersii (Decapoda, Palaemonidae). Journal of Crustacean Biology, 23(4): 862-868.

Oliveira, L.J.F.; Sant'Anna, B.S. \& Hattori, G.Y. 2017. Reproductive potential of four freshwater prawn species in the Amazon region. Invertebrate Reproduction \& Development, 61(4): 290-296.

Pantaleão, J.A.F.; Hirose, G.L. \& Costa, R.C. 2012. Relative growth, morphological sexual maturity, and size of Macrobrachium amazonicum (Heller 1862) (Crustacea, Decapoda, Palaemonidae) in a population with an entirely freshwater life cycle. Invertebrate Reproduction \& Development, 56(3): 180-190.

Pantaleão, J.A.F.; Hirose, G.L. \& Costa, R.C. 2014. Ocurrence of male morphotypes of Macrobrachium amazonicum (Caridea, Palaemonidae) in a population with an entirely freshwater life cycle. Brazilian Journal of Biology, 74(3): S223-S232.

Paschoal, L.R.; Guimarães, F.J. \& Couto, E.C. 2013. Relative growth and sexual maturity of the freshwater shrimp Palaemon pandaliformis (Crustacea, Palaemonidae) in northeastern of Brazil (Canavieiras, Bahia). Iheringia. Série Zoologia, 103(1): 31-36.

Peebles, J.B. 1977. A rapid technique for molt staging in live Macrobrachium rosenbergii. Aquaculture, 12(2): 173-180.

Peebles, J.B. 1979. Molting, movement and dispersion in the freshwater prawn Macrobrachium rosenbergii. Journal of the Fisheries Board of Canada, 36: 1080-1088.

Pereira, M.D.G.C. \& Chacur, M.M. 2009. Estrutura populacional de Macrobrachium brasiliense (Crustacea, Palaemonidae) do Córrego Escondido, Batayporã, Mato Grosso do Sul, Brasil. Revista de Biologia Neotropical, 6(1): 75-82.

Pereira, R.T.; Almeida, A.C.; Teixeira, G.M.; Bueno, A.A.P. \& Fransozo, A. 2017. Reproductive strategy of the shrimp Nematopalaemon schmitti
(Decapoda, Caridea, Palaemonoidea) on the southeastern coast of Brazil. Nauplius, 25: (e2017003):1-8.

Pescinelli, R.A.; Carosia, M.F.; Pantaleão, J.A.F.; Simões, S.M. \& Costa, R.C. 2016. Population biology and size at the onset of sexual maturity of the amphidromous prawn Macrobrachium olfersii (Decapoda, Palaemonidae) in an urban river in southeastern Brazil. Invertebrate Reproduction \& Development, 60(4): 254-262.

Pileggi, L.G.; Magalhães, C.; Bond-Buckup, G. \& Mantelatto, F.L.M. 2013. New records and extension of the known distribution of some freshwater shrimps in Brazil. Revista Mexicana de Biodiversidad, 84(2): 563-574.

Rocha, S.S. \& Barbosa, R.J. 2017. Population biology of Macrobrachium jelskii (Miers, 1877) (Decapoda, Palaemonidae) from an artificial pond in Bahia, Brazil. Nauplius, 25 (e2017023):1-13.

Román-Contreras, R. \& Campos-Lince, L.S. 1993. Aspectos reproductivos y aproximación a un modelo de crecimiento para una población de Macrobrachium acanthurus (Wiegmann, 1836) en el río Palizada, Campeche, México. Anales del Instituto Ciencias del Mar y Limnologia, 20(1): 78-96.

Sampedro, M.P.; González-Gurriarán, E.; Freire, J. \& Muiño, R. 1999. Morphometry and sexual maturity in the spider crab Maja squinado (Decapoda: Majidae) in Galicia, Spain. Journal of Crustacean Biology, 19(3): 578-592.

Sastry, A.N. 1983. Ecological aspects of reproduction. In: Vernberg, F.J. \& Vernberg, W.B. (Eds.). The biology of Crustacea: environmental adaptations. New York, Academic of Press. v. 8, p. 179-270.

Silva, R.R.; Sampaio, C.M.S. \& Santos, J.A. 2004. Fecundity and fertility of Macrobrachium amazonicum (Crustacea, Palaemonidae). Brazilian Journal of Biology, 64(3A): 489-500.

Soares, M.R.; Oshiro, L.M.Y. \& Toledo, J.C. 2015. Biologia reprodutiva de Macrobrachium jelskii (Crustacea, Decapoda, Palemonidae) no rio São Francisco, Minas Gerais, Brasil. Iheringia, Série Zoologia, 105(3): 307-315.

Sturges, H.A. 1926. The choice of a Class Interval. Journal of the American Statistical Association, 21(153): 65-66.

Taddei, F.G.; Reis, S.D.S.; David, F.S.; Silva, T.E.D.; Fransozo, V. \& Fransozo, A. 2017. Population structure, mortality, and recruitment of Macrobrachium amazonicum (Heller, 1862) (Caridea: Palaemonidae) in the eastern Amazon region, Brazil. Journal of Crustacean Biology, 37(2): 131-141.

Valenti, W.C. 1985. Cultivo de camarões de água doce. São Paulo, Nobel. 82p.

Valenti, W.C.; Lobão, V.L. \& Mello, J.T. 1989. Crescimento relativo de Macrobrachium acanthurus (Wiegmann, 1836) (Crustacea, Decapoda, Palaemonidae). Revista Brasileira de Zoologia, 6(1): 1-8.

Valenti, W.C.; Mello, J.D.T.C.D. \& Castagnolli, N. 1993. Efeito da densidade populacional sobre as curvas de crescimento de Macrobrachium rosenbergii (de Man) em cultivo semi-intensivo (Crustacea, Palaemonidae). Revista brasileira de Zoologia, 10(3): 427-438.

Volpato, G.L. \& Hoshino, K. 1984. Adaptive processes derived from the agonistic behavior in the freshwater prawn Macrobrachium iheringi (Ortmann, 1897). Boletim de Fisiologia Animal, São Paulo, 8: 157-163.

Wehrtmann, I.S. 1990. Distribution and reproduction of Ambidexter panamense and Palaemonetes schmitti in Pacific Costa Rica (Crustacea, Decapoda). Revista de Biología Tropical, 38(2A): 327-329, 1991.

Weiss, R.; Anger, K.; Hayd, L. \& Schubart, C.D. 2015. Interpreting genetic distances for species recognition: the case of Macrobrachium amazonicum (Heller, 1862) and the recently described M. pantanalense Dos Santos, Hayd \& Anger, 2013 (Decapoda, Palaemonidae) from Brazilian fresh waters. Crustaceana, 88(10-11): 1111-1126.

Wilson, M.F. \& Pianka, E.R. 1963. Sexual selection, sex ratio and mating system. American Naturalist, 97: 405-407.

Zar, J.H. 2010. Biostatistical analysis. New Jersey, Prentice Hall. 718p. 